\section{Journal of the British Association for the Study of Religions}

JBASR 19 (2017), 8-17

ISSN: 2516-6379

\title{
A Woman of Many Parts
}

\author{
Peggy Morgan \\ Mansfield College, Oxford \\ peggy.morgan@mansfield.ox.ac.uk
}

\begin{abstract}
This article seeks to demonstrate the wide-ranging nature of Professor Ursula King's research and intellectual interests within the field of religious studies. It highlights her personal engagement not only with issues in science, ecology and religions, Hinduism, education, spirituality, feminist and gender studies on an international stage, but also her involvement dialogically with the people whose work and religious lifeways she has encountered. It shows a continuing and remarkable vitality and freshness in an arena of interests across both local, personal and global issues.
\end{abstract}

My academic books are distributed on shelving in many different parts of my home and are grouped in a roughly thematic way. Whilst most scholars' works are located in one main area, Professor Ursula King's publications can be found in a variety of sections. They emerge from within a range of locations which are therefore discovered anew as I go to find some volumes I need to consult.

The readers of this journal edition, which has been compiled to honour Ursula King's eightieth birthday, will most readily associate her work with the British Association for the Study of Religions. She has held various posts, is a former President and has been elected an honorary life member as a distinguished international scholar working within its very wide-ranging multidisciplinary field.

However, with the personal perspective that colours all our engagement with each other and our academic work, I am going go further back than these links and begin more personally to recall a lecture I heard Charles Raven give at the Leicester Theological Society when I returned to my home town during a vacation from University in the early 1960s. This lecture introduced me to 
the work and life of the Jesuit Pierre Teilhard de Chardin (1881-1955) and it was my first real engagement not only with his work but also with the science and theology/religion debates. The event was linked to the publication of Charles E. Raven's Teilhard de Chardin Scientist and Seer. I still have the notes from the lecture alongside my copies of some of Chardin's writings. So it was of personal interest when I found that at a similar time in 1962 Ursula King tells us she had her interest in Chardin aroused by lectures in Paris where she was then a student (King, 1996, ix) and two of her books on Chardin sit next to my notes and the copies of his works. That interest from the science and religions perspective and more was acknowledged by the pioneering Cambridge academic Joseph Needham who had met Chardin in Paris in 1947 and wrote the forward to Ursula King's 1980 volume Towards a New Mysticism. Teilhard de Chardin and Eastern Religions. Needham affirms her use of new material and her exploration of Teilhard's eastern journeys and their influence on his thinking. In that volume Ursula King acknowledges that Teilhard's 'approach to Eastern religions has very definite shortcomings' and that he did not 'travel' in his encounters far enough, but that nevertheless 'Teilhard's mystical experience and vision may prove a stimulus to those engaged in the study of religion and the meeting of world faiths, as well as all those who are searching for a new direction in contemporary spirituality' (1980, 16-17). In her epilogue to that volume Ursula King affirms the 'need to go beyond Teilhard' and she has continued to re-visit her work on him and contextualise him in further publications within the modern searches for a new spirituality. For example, in the 2011 Teilhard de Chardin and Eastern Religions. Spirituality and Mysticism in an Evolutionary World key phrases for Ursula King's own work in the above quotation and themes to all of which we shall return are 'mystical experience; 'the study of religions'; 'the meeting of world faiths', and 'contemporary spirituality'.

Some will be surprised that so much of Ursula King's research time has been spent on the thinking of a male scholar and also react to the considerable interest in spirituality and theology in one that we honour for her contribution to the academic study of religions. For many, including myself, the separation of theology and study of religions has been an important base line of academic life from the 1967 Lancaster experiment onwards. And for others the use of the term spirituality is suspect. (Carette \& King 2005, passim). On the first point raised of possible surprise, we need to remind ourselves that Ursula King has frequently advocated that we think in terms of gender studies. In this emphasis the places, positions and perceptions of both women and men and the relationships between them is of more concern than women's and feminist studies only, though her contribution to the latter has been notable. And of course the spectrum of contemporary LGBT studies widens the field even more. Also, Ursula King points out how much input various women she names, and from whose correspondence she quotes, had in Teilhard's life and work (1996. x). Those examples can be seen by others in a critical way as the classic syndrome of 'women supporting a great man so that he can flourish' (my words). But Ursula King is careful to call the women themselves extraordinary and to name their personal inspiration as well as their support and also to quote their own words. 
The second point mentioned above is linked to the introduction of the concept of spirituality into the discussion and can be seen as a move from the study of religions back towards theology. This criticism was certainly my experience when I was Director of The Religious Experience Research Centre (RERC, but originally the Religious Experience Research Unit, RERU) between 1996 and 2002. One of the central founding documents of RERU was by another scientist and evolutionist, Professor Sir Alister Hardy whose ideas are encapsulated in his 1979 The Spiritual Nature of Man. This volume is an account of the first ten years of the then Unit's research. Hardy's influential Oxford tutor was Julian Huxley who wrote the introduction to the Collins 1960 translation of Chardin's The Phenomenon of Man and Hardy introduces a discussion of Chardin's ideas in the first of his Aberdeen 1965 Gifford lectures The Living Stream: Evolution and Man. He discusses some of the problems with seeing The Phenomenon of Man, in Chardin's words, 'purely and simply as a scientific treatise'. Hardy affirms it as 'a magnificent epic, almost a poem of the rise and emergence of the spirit of man and his feeling after Divinity. If it had been published as such one would have regarded it as a glorious, if somewhat wildly metaphorical, expression of faith, and that indeed is how I would like to regard it. One feels that it might well be illustrated by engravings by Blake' $(1965,18)$.

In my work as Director of RERC I focused on adding to the archives of that centre and making research on the material more multi faith and multidisciplinary in line with a rigorous study of religions approach that is my background. In this I had the invaluable support on the board of trustees and in research advice from Ursula King in the complex years when I moved the archives of the centre to Lampeter, where research is now overseen by the anthropologist Professor Bettina Schmidt. As a distinguished guest speaker Ursula King gave the annual lecture in 2002 which is published in the Centre's second series of occasional papers as number 48 Ecological and Mystical Experience from an Interfaith Perspective (University of Wales). In it she uses her insights into Chardin's experience during night watches in the trenches of the first world war where he sees the world as one great 'thing', as if from the moon, and Ursula King links that with the famous moon-landing's image of our globe, as Earthrise. She ranges widely over contemporary ecological thinking, some of which derives from political statements, some from ecologists in the scientific community and some from those within religious traditions. On June $3^{\text {rd }} 2017$, she continued her support for the Centre by speaking alongside Keith Ward at a joint Alister Hardy Trust and British Teilhard Association day in London on Ecology, Science and Spirituality- Friends or Enemies? which sought to build on the legacy of Teilhard de Chardin and Alister Hardy and included the thinking of Thomas Berry. The summary for her lecture contains something of her very positive view "What "Great Work" is required for the further social, cultural and spiritual evolution of humanity and a sustainable future for all life on Earth? And how far does this require a greater evolution of the transformative powers of love?' She has written more widely on this area in the 2009 The Search for Spirituality. Our global quest for meaning and fulfilment. Both global spirituality and ecology obviously subjects about which she feels passionately, and I would suggest this deep feeling, this passion is part of most of her work and interactions. These issues matter in a very 
personal way and she is often featured in the 'women of spirit' group photographs sponsored by the Brahma Kumaris, a movement that originated in India and that is led by women. It sees itself not as a Hindu new religious movement but as a World Spiritual University, and they are listed in the procession of delegates at the 1993 anniversary Chicago Parliament of The World Religions gathering not as Hindus but as Brahma Kumaris represented by Ven. Sister Pratima in A Global Ethic: Declaration of The Parliament of The World's Religions on the Global Ethic (1993, 110). This influential declaration was published after the Chicago Centenary Anniversary of the 1893 Parliament of The World's Religions.

Being involved with movements such as the Brahma Kumaris and with other interfaith activities demonstrates that Ursula King is not a person of cold, academic objectivity in her participations and investigations and one of the things she appreciates and has appreciated about other scholars is the fullness of their human involvement in their subjects of study. For example, she says of Geoffrey Parrinder with whom she studied for her PhD at King's College, London, that he 'impressed me with his warm generosity of spirit, helping his students to have a broad ecumenism that welcomed the insights of those faiths other than their own. I am grateful for having thus been prepared for the cultural and religious pluralism as characteristic of our time.' (1990, ix) Turning Points in Religious Studies. In 1990 she edited that important collection of essays Turning Points in Religious Studies, which marks a particular stage of developments and interests in the field to honour Geoffrey Parrinder in his $80^{\text {th }}$ year. The contents are rich in their range and in the scholars who agreed to contribute. Notable is the inclusion of the study of religions / religious studies in schools and colleges, for the tradition founded at Lancaster in 1967, and that is close to my heart, is that education in religions done with empathy and sympathetic imagination is an enterprise important throughout the lifetime of the scholar and student...from the cradle to the grave. And Ursula King, amongst many others from all levels of education and mentioned elsewhere in this article, have been loyal members of the Shap Working Party on World Religions in Education (now the Shap Working Party on Religion in Education). This was founded in 1969 and named after the Shap Wells Hotel in Cumbria where the first meeting was held. It has been for many of us a strong network of personal as well as professional friendships and for Ursula there was a lifetime shared vision with W Owen Cole (now deceased) and his family right from their original meeting in Leeds. Examples of her commitment are not only her regular attendance at Shap meetings but when called upon Ursula King has contributed to their publications from her own wide expertise, for example on Looking at the Bhagavad Gita in a Wider Context (1989, 46 ff.) in Angela Wood's compilation Religions and Education and Women and World Religions (ibid. 98ff.), which demonstrates the diversity of her expertise. The intention of these pieces is that they are accessible and stimulate further work in teaching at various levels. Many academics are not able to make their ideas particularly accessible but these pieces do that successfully in my opinion. Women and World Religions, which is a predictable topic from what we know of Ursula King's work, begins with a focus on need. 'A close look at Religious Studies and RE materials soon discloses an almost total unawareness of the 
existence of women ... And again, when one looks at women's studies courses and programmes one often, too, notes a surprising absence of concern pertaining to religion' (ibid. 98). The reader might at this point check how far in their experience this is still the case. In the other topic Looking at The Bhagavad Gita in A Wider Context. (ibid. 46-49) she indicates that many approaches are from a 'rather limited and too literal perspective' and advocates the need 'to explore a number of different yet complementary approaches. Historical, exegetical, theological and comparative' (ibid. 46). Both the pieces referred to above have helpful and detailed endnotes including bibliographies which take the interested reader deeper into the material.

One interesting approach to the Bhagavad Gita was pursued in an edition of the Journal of Dharma vol. VII no. 2 April-June 1982 on Religion and Art. This journal originates in the pioneering Centre for The Study of World Religions Dharmaram College, Bangalore and draws on the work of a team of international scholars. I think I recollect rightly that Ursula King has an extensive collection of visual material on the Bhagavad Gita and is a very visual person. V. Francis Vineeth, the journal's Associate Editor points out in his editorial (ibid.127) that 'Religion and art have this in common: they create syntheses from the disparate elements in life'. Ursula King's piece on The Iconography of The Bhagavad Gita (ibid.146-163) ranges widely both on the history of the iconography and the meaning of the text's 'visual theology' for Hindus in their spiritual experience.

Flowing naturally on from any mention of spirituality and religious experience and for me one type within those overall and often misunderstood, umbrella terms, is the study of mysticism, again an overlap with some of Parrinder's (Parrinder, 1996) as well as Chardin's wide interests. Here again King has made a significant contribution and her beautifully illustrated book on Christian Mystics (1998) which is sub-titled The Spiritual Heart of the Christian Tradition. It once more illustrates the importance of the visual for Ursula King in the choice of beautiful and apt illustrations. I particularly like the atmospheric painting of a beguine gently overseeing a small child's sweeping by Norman Garstin (1847-1926) in the section on the beguines and beguinages $(1998,94)$. I once stayed in a beautifully preserved beguinage in Leuven when I was overseeing a group of Erasmus exchange students. It now provides the University's guest facility but still preserves and evokes, in my opinion, something of the simple and deeply spiritual everyday rhythm of life of these laywomen.

When I was looking back at this book on mysticism, I found a card to thank me for organising the fiftieth anniversary conference of BASR at which she gave the annual lecture. It was my swan song as a BASR conference organiser and it took me back to the first time I was asked to take that role when Ursula King was BASR's honorary president and when she hardly knew me. The arrival of the card after the 2004 conference was typical of her consideration of the effort involved in organising such an event and has been illustrated in relation to whatever our encounters and meetings have been and I have found in her a courtesy over the years that is rarer and rarer in today's pressurised more impersonal academic environment. She also keeps in touch 
with people and their partners even when they have moved away from their positions of power and influence or in the case of some partners are widows (and it could be widowers). Whilst I was writing this piece Irene Williams (the widow of Cyril Williams, BASR President from 1984-1988 and a pioneer of the study of religions in Wales rang me and mentioned Ursula, as did Libushka Smart (the now deceased widow of Ninian Smart) whenever we were in touch. Also, whilst I was 'breaking ground' on this article in January 2017 I had a typical e-mail (sometimes it is a card) from Ursula which had personal news and warm greetings but also news of another scholar. She has worked with so many of our key scholars and for such a significant amount of time and these memories and personal contacts are to my mind very precious in the history of our field. Her links are very international as well as local. Some people call this networking but I have always heard in Ursula a human warmth in such contacts and remembrances which the term 'networking' belies. She asked on this occasion:

'Did you know Richard Lannoy who has just died? He will be cremated in Bournemouth tomorrow. It so happened that I ran into an old friend at the doctor's surgery yesterday and she, who is much involved with the cremation, told me all about it. My mobility is not good enough to make it to Bournemouth tomorrow, alas, but I have fond memories of Richard from earlier years. I first came across his work when his "Speaking Tree" was published in paperback (1974) and I used it for teaching. I have just found it on my shelves, together with a joint discussion with Dorothy Emmet, Richard Lannoy, Julius Lipner and myself in Cambridge about 1980 (published in Theoria to Theory magazine 1981). I had forgotten all about it, but it was perhaps my first meeting with Richard Lannoy. I last saw him some years ago when he invited me to visit an exhibition of his paintings in Bath. Later we regularly exchanged Christmas cards, but as I had not heard from him last year, I had been wondering what was happening.'

Ursula has often re-visited and revised her earlier work, as recently with the Oxford Bampton lectures originally given in 1996, but she also enjoys exploring newer arenas and always eagerly engages with what is happening amongst contemporary artists and thinkers. At one point we discovered a common interest and enthusiasm for the composer Jonathan Harvey (19392012) whom I had heard deliver one of the annual Hussey lectures on The Church and The Arts in Oxford, I think in about 1999, and then I followed something of his work afterwards. In Harvey's lecture he quoted from Venerable Sangharakshita the Buddhist leader and founder of what was originally The Western Buddhist Order and Friends of The Western Buddhist Order (since 2010 Triratna), who is /was also a poet and supporter of the arts. This reference to Sangharakshita in a room in the Examination Schools and in a Theology Faculty context in Oxford was in itself enough to capture my attention and interest for being unusual. Much later, at another of her good friend Hans Küng's invitation, Ursula went to Berlin for the premier of Harvey's Weltethos, later performed also in Birmingham in 2011. The basic principle of the theologian Hans Küng "There will be no peace among the nations without peace among the religions" (Küng \& Kuschel, eds.1993) forms the basis of the libretto to the choral work Weltethos. According to Küng, the political and 
ecological challenges of the future are to be mastered only with a basic consensus spanning all cultures. Weltethos is the vision of this arrangement, based on the common values of the world religions. In the piece these are conveyed in texts about Confucius, Moses, Muhammed, Buddha and Jesus as well as Hindu writings. The result should, according to Küng, be no "religious potpourri" but a universal message of nonviolence, justice, truthfulness and partnership.

In the opinion of the conductor Simon Rattle, who at that time was conducting the Berlin Philharmoniker, Jonathan Harvey is probably the most spiritual of our British composers. In addition, his knowledge of India, Chinese and Arabic music predestines him for this project in a unique way. Harvey has been a good friend of the Berliner Philharmoniker and the Berliner Rundfunkchor ever since the musicians gave the German premier of Harvey's Madonna of Winter and Spring, conducted by Simon Rattle.

When Ursula told me about her visit to hear Weltethos, with her typical enthusiasm for the occasion and the piece, I was able to describe the work of Harvey that I knew. I showed and leant her some books of Harvey's I had, such as In Quest of Spirit: Thoughts on Music (University of California Press 1999), a CD and Arnold Whittall's handbook Jonathan Harvey (Faber and Faber, 1999) and enthused about various of his works such as Nataraja, where he blends East and West, one of the hallmarks of his work, and which I have used when the opportunity arose. Alongside it I had used the modern painting on the same theme of Nataraja by Bridget Riley (1993) whose diagonal, complex colour stripes emphasise the rhythm and counter rhythm of Shiva's dance. Ursula's response when she returned the book and CD on Jonathan Harvey was with the usual interesting postcard which said that listening to his music 'was much appreciated' and that it 'stretches one's mind and soul - it demands intense listening'. This composer's written work in which, like many others, he prefers the term spirituality to the word religion, had been recommended to me by Bishop John Taylor (1914-2001), then retired from Winchester where he had directed Jonathan Harvey's Passion and Resurrection in the cathedral in 1981. John Taylor was himself a poet and his love of the arts and the perception that he had the soul of a mystic and an artist were commented on in obituaries after his death. John Taylor was also a long-term supporter of the work of the Alister Hardy Religious Experience Research Centre (RERC) and may have introduced Harvey to its work, for Harvey's words on art and the experience of transcendence at the beginning of chapter 4 of his book In Quest of Spirit: Thoughts on Music are profound, and he mentions the accounts of mystical experiences in the archives of RERC. It is always satisfying when explorations, such as this short article into the work of Ursula King, demonstrate how inter-connected our lives and interests are, for as is mentioned elsewhere. As already mentioned, Ursula King has always supported the work of RERC in a variety of ways.

The desire for an appropriate breadth and gender balance in our academic work which has been a distinctive feature of Ursula King's work was illustrated in a strong review she wrote of the first printed edition of Mircea Eliade's edited multi-volumed Encyclopedia of Religion (Macmillan Publishing 
Company, 1987, now with a second edition by Lindsay Jones, Macmillan and Thomson Gale, 2005, and available online). Many of us did not see beyond being excited by the original enterprise, but in her usual incisive way Ursula King both interrogated the issue of the pieces on women scholars in the work and pointed out the deficiencies such as how relatively few women scholars were included. For the second edition she became a consultant and as a result the gender balance is much improved.

In the arena of feminist and gender studies Ursula King has made many notable contributions, as with the example of broadening the themes of work on Teilhard mentioned above. This has included widening the field to include local cultures not always at one time embraced in academic research. She was involved from its beginning in the community religions project pioneered in Leeds which produced studies of local community life investigated through participant observer research. Many of these were by the Leeds's department of Theology and Religious Studies' doctoral students and their work helped to launch their academic careers. King's personal support of, for example, her undergraduate and research students both in Leeds and Bristol, some of whom readers will find contributing to this volume, has been exemplary. But very significant to me and derived from her international encounters with a variety of women's voices expressed in a variety of ways, is the very varied 1994 Feminist Theology From The Third World: A Reader which she edited. She expresses in her Introduction any problems with terminology and selection and something of the history of the global awareness of these issues and then presents a rich collection of contributions with the memorable ending from the section on Women's Oppression and Cries of Pain to the piece on Dalit theology.

There is a Cry, let us listen

There is a Call, let us respond

There are committed ones

Let us communicate the strategy. (1994,137)

Here is a link with Ursula King's early time in India which has provided such a rich resource in many ways for foci on aspects of its major religious traditions and of friendships formed with other scholars such as Professors Margaret Chatterjee and Kitty Datta. But reflection on the setting of this Indian link and family of traditions, urges me to make a general and very personal point about Ursula King, for which I hope to be forgiven / excused. Many have found her outspoken, critical and fierce at times and latterly I have placed that in the context of how we need to understand Kali or Durga, the Hindu manifestation of the goddess as fierce. Speaking up, being confrontational and sometimes angry are expressed in Kali in order to 'fight' evil and injustice, to challenge the world's wrongs. This is seen as necessary and it is in this light that I have grown to appreciate Ursula King's ability to speak out when she has deemed it necessary. Nearer to home we can vividly remember the way the early suffragettes were viewed as they went into 'battle'. We can all hope, Ursula included, there will in future be less need for such fierce engagement on whatever cause. 
I have ranged very widely in this piece and sometimes personally but that is because Ursula King herself has explored the multifaceted field of the study of religions across many boundaries and traditions. I have not, of course, touched on all her interests, activities and writing, of her recent involvement with the Committee for the Templeton Prize for Progress in Religion and my experience of her supportive role as an external examiner. But the many gaps will be filled by others' contributions to this volume. She is one of our talented continental Europeans by origin who has chosen to make her academic contribution from bases in UK both in Leeds and Bristol, but who has never ceased to be a world citizen in what she learned in India from her time there, about Africa from Geoffrey Parrinder, and more recently in her excitement in visiting China and experiencing the silk roads.

I shall end in wishing Ursula every happiness in her further years of active retirement, with a quotation she uses from the work of the thinker to whom she has most frequently returned, Pierre Teilhard de Chardin from his 'Reflections on Happiness' $(1996,185)$. 'We must, it is true, sink our roots deep into the rich, tangible, material realities which surround us; but in the end it is by working to achieve our own inner perfection - intellectual, artistic, moral- that we shall find happiness ... Through and beyond matter, spirit is hard at work, building'.

\section{References}

Carrette, J.R. \& R. King (2005) Selling Spirituality: The Silent Take Over of Religion. London: Routledge.

Chatterjee, M. (1989) The Concept of Spirituality. New Delhi: Allied Publishers Private Ltd.

Eliade, Mircea (ed.) (1987) Encyclopedia of Religion, multi-volumed, London: Macmillan Publishing Company.

Franklin, J. (2014) [2006]. Exploration Into Spirit: A History of The Alister Hardy Religious Experience Research Centre and Society, 2nd ed. Lampeter: The Alister Hardy Society.

Hardy, A. (1965) The Living Stream: Evolution and Man. London: Collins.

Hardy, A. (1979) The Spiritual Nature of Man. Oxford: Clarendon Press.

Harvey, Jonathan (1999) In Quest of Spirit: Thoughts on Music. California, University of California Press, with a CD.

Jones, Lindsay (ed.) (2005) Encyclopedia of Religion, $2^{\text {nd }}$ ed. London: Macmillan and Gale publishing on-line.

King, Ursula (1980) Towards a New Mysticism. Teilhard de Chardin and Eastern Religions. London: Collins. 
King, Ursula (ed.) (1990) Turning Points in Religious Studies. Edinburgh: T and T Clark.

King, Ursula (ed.) (1994) Feminist Theology From The Third World: A Reader London: SPCK and Orbis Press.

King, Ursula (1998) Christian Mystics: The Spiritual Heart of The Christian Tradition. London: B.T. Batsford.

King, Ursula (2011) Teilhard de Chardin and Eastern Religions. Spirituality and Mysticism in an Evolutionary World. Mahwah, New Jersey: Paulist Press.

King, Ursula (2015) [1996] Spirit of Fire, 2nd ed. Maryknoll, New York: Orbis Books.

King, Ursula (2009) Ecological and Mystical Experience from an Interfaith Perspective. Lampeter: University of Wales.

King, Ursula (2009) The Search for Spirituality. Our global quest for meaning and fulfilment. Norwich: Canterbury Press.

King, Ursula (2016) [1996] Christ in All Things. Exploring Spirituality with Pierre Teilhard de Chardin, 2nd. ed. Oxford: OUP

Küng, Hans \& Karl-Josef Kuschel (eds) (1993) (tr. John Bowden) A Global Ethic: Declaration of The Parliament of The World's Religions on the Global Ethic. London: SCM Press Ltd.

Parrinder, Geoffrey (1976) Mysticism in The World's Religions. London: Sheldon Press.

Riley, Bridget (1998) Works (1961-1998). Exhibition Catalogue: Abbot Hall Art Gallery Kendal.

Sangharakshita (1980) The Religion of Art: Windhorse Publications.

Raven, Charles E. (1962) Teilhard de Chardin, Scientist and Seer. London: Collins.

Whittall, Arnold (1999) Jonathan Harvey. London: Faber and Faber.

Wood, Angela (ed.) (1989) Religions and Education: Shap Working Party 1969-1989 London: BFSS National RE Centre. 